(C) 2022, The Authors. Published by Elsevier Inc. and Fass Inc. on behalf of the American Dairy Science Association ${ }^{\circledR}$. This is an open access article under the CC BY license (http://creativecommons.org/licenses/by/4.0/).

\title{
Effect of supplement crude protein concentration on milk production over the main grazing season and on nitrogen excretion in late-lactation grazing dairy cows
}

\author{
M. J. Doran, ${ }^{1 *} \odot$ F. J. Mulligan, ${ }^{2} \odot$ M. B. Lynch, ${ }^{1,3} \odot$ A. G. Fahey, ${ }^{1} \odot$ N. J. Ryan, ${ }^{2}$ C. McDonnell, ${ }^{1} \odot$ S. McCabe, ${ }^{1}$ \\ and K. M. Pierce ${ }^{1}$ (D) \\ ${ }^{1}$ School of Agriculture and Food Science, University College Dublin Lyons Research Farm, Celbridge, Naas, Co. Kildare, Ireland, W23 ENY2 \\ ${ }^{2}$ School of Veterinary Medicine, University College Dublin, Belfield, Dublin 4, Ireland, D04 V1W8 \\ ${ }^{3}$ Teagasc Environment Research Centre, Johnstown Castle, Wexford, Ireland, Y35 Y521
}

\begin{abstract}
The objectives of this study are to evaluate the effects of (1) a potential interaction between supplement crude protein $(\mathrm{CP})$ concentration and differing cow genotypes on milk production, (2) differing cow genotypes on milk production, and (3) decreasing the supplement $\mathrm{CP}$ concentration on milk production and $\mathrm{N}$ excretion during the main grazing season within a spring-calving herd. A $2 \times 2$ factorial arrangement experiment, with 2 feeding strategies $[14 \% ; \mathrm{n}=30$ (lower $\mathrm{CP} ; \mathrm{LCP}$ ) and $18 \%$; n $=28$ (higher CP; HCP) CP concentrate supplements] offered at varying levels according to pasture availability and days in milk (DIM) was conducted over the main grazing season from April 3 to September 3, 2019, at University College Dublin Lyons Farm. Cows were also grouped into 2 genotype groups: lower milk genotype; $\mathrm{n}=30$ [LM; milk kg predicted transmitting ability (PTA): $45 \pm 68.6$ (mean $\pm \mathrm{SD}$ ); fat $\mathrm{kg}$ PTA: $10 \pm 4.9$; and protein $\mathrm{kg}$ PTA: $7 \pm 2.3]$ and higher milk genotype; $\mathrm{n}=28$ [HM; milk kg PTA: $203 \pm 55.0$; fat $\mathrm{kg}$ PTA: $13 \pm 3.8$; and protein $\mathrm{kg}$ PTA: $10 \pm 2.4$ ] A total of 46 multiparous and 12 primiparous (total; 58) Holstein Friesian dairy cows were blocked on parity and balanced on DIM, body condition score, and Economic Breeding Index. Cows were offered a basal diet of grazed perennial ryegrass pasture. The N partitioning study took place from August 25 to 30, 2019 $(187 \pm 15.2 \mathrm{DIM})$. No interactions were observed for any milk production or milk composition parameter. No effect of supplement CP concentration was observed for any total accumulated milk production, daily milk production, or milk composition parameter measured. The HM cows had increased daily milk yield $(+1.9 \mathrm{~kg})$,
\end{abstract}

Received May 14, 2021.

Accepted August 24, 2021.

*Corresponding author: michael.doran@ucdconnect.ie fat and protein $(+0.15 \mathrm{~kg})$, and energy-corrected milk $(+1.7 \mathrm{~kg})$, compared with the LM cows. Furthermore, HM cows had decreased milk protein concentration $(-0.1 \%)$ compared with LM cows. For the N partitioning study, cows offered LCP had increased pasture dry matter intake (PDMI; $+0.9 \mathrm{~kg} / \mathrm{d})$, dietary $\mathrm{N}$ intake $(+0.022 \mathrm{~kg} / \mathrm{d})$, feces $\mathrm{N}$ excretion $(+0.016 \mathrm{~kg} / \mathrm{d})$, and decreased $\mathrm{N}$ partitioning to milk $(-2 \%)$, and $\mathrm{N}$ utilization efficiency $(-2.3 \%)$. In conclusion, offering cows LCP had no negative influence on milk production or milk composition over the main grazing season where high pasture quality was maintained. However, any potential negative effects of offering LCP on milk production may have been offset by the increased PDMI. Furthermore, offering cows LCP decreased N utilization efficiency due to the higher PDMI and feed $\mathrm{N}$ intake associated with cows on this treatment in our study. Key words: dairy cow, genotype, supplement crude protein, milk production, nitrogen excretion

\section{INTRODUCTION}

Nitrogen losses can negatively impact air $\left(\mathrm{NH}_{3}\right)$, and both groundwater and surface water $\left(\mathrm{NO}_{3}\right)$ quality (Tamminga, 1992; Owens et al., 1994; EPA, 2017). The European Union (EU) Nitrates Directive (91 676 EEC) has been in place since 1991 and aims to protect water quality from pollution originating from agricultural sources and promote the use of good farming practice. Nitrogen utilization efficiency (NUE) is poor in dairy cows (Ipharraguerre and Clark, 2005), which can be exacerbated in grazing systems because high-quality grazed pasture is naturally high in CP (Van Vuuren et al., 1990), with a value of $18.5 \%$ CP being defined as high by Kopp et al. (2019). As a result, large amounts of $\mathrm{N}$ loss occur when dairy cows are grazing outside (Casey and Holden, 2005). Typically, NUE ranges from 12 to $25 \%$ in Irish grazing studies and can be dependent on stage of lactation (Whelan et al., 2012; 
Reid et al., 2015a; McKay et al., 2019). Furthermore, it is known that urinary $\mathrm{N}$ is the most environmentally harmful route of $\mathrm{N}$ excretion in dairy cows (Pakro and Dillon, 1995), but it is also the most labile with differing dietary strategies (Burke et al., 2008; Whelan et al., 2012). It is of interest, therefore, to investigate options for reducing $\mathrm{N}$ excretion or altering the route of excretion in grazing dairy cows. Some evidence (Cheng et al., 2014) suggests an effect of genotype on milk N output, whereas Huhtanen et al. (2015) showed that dietary means have more of an effect.

Irish milk production relies predominantly on a spring-calving grazing system, typically utilizing concentrate supplementation (CS) when availability and quality of grazed pasture are reduced (Dillon et al., 2008; McEvoy et al., 2008). Past research has shown that CS has increased milk yield (Bargo et al., 2003; Kennedy et al., 2003; McKay et al., 2019), milk solids yield (O'Brien et al., 1996), and lactation length (Kellaway and Harrington, 2004). Additionally, when grazed pasture is the sole feed, the opportunity for dietary manipulation of $\mathrm{N}$ excretion is limited; however, offering cows CS allows the substitution of a proportion of the diet higher in CP (pasture) with a lower-CP CS (Reid et al., 2015a; McKay et al., 2019). Decreasing the supplement $\mathrm{CP}$ concentration has reduced urinary $\mathrm{N}$ excretion in recent past studies (Whelan et al., 2012; Hynes et al., 2016), thus potentially reducing the environmental impact associated with pasture-based dairy production. However, results of these studies that also investigate effects of supplement $\mathrm{CP}$ on milk production are variable, focus on a particular lactation stage only, and do not provide results of total accumulated milk production over the main grazing season (Whelan et al., 2012; Hynes et al., 2016). Additionally, farmers that operate more intensive milk production systems within the EU must now reduce feed $\mathrm{N}$ inputs to comply with nitrates derogation legislation (DAFM, 2021).

Aside from differing dietary strategies, genetic improvement is a viable alternative strategy that can be used to improve milk production levels while simultaneously reducing the environmental footprint of dairy production systems (Berry, 2013; Lahart et al., 2021). For example, Cheng et al. (2014) showed that improvements in milk production through genetic selection (Breeding Worth, New Zealand) resulted in an associated increase in milk $\mathrm{N}$ output leading to a higher NUE. However, differences in milk production between cows that score highly on the grazing-oriented Economic Breeding Index (Ireland), but have divergent fat and protein yield $(\mathrm{kg})$ PTA, have not been evaluated. This research could be important for farmers who want more information on genotypes to improve milk production and simultaneously reduce environmental impact.

The objectives of this study are to evaluate the effects of (1) a potential interaction between supplement $\mathrm{CP}$ concentration and differing cow genotypes on milk production, (2) differing cow genotypes on milk production, and (3) decreasing the supplement CP concentration on milk production and $\mathrm{N}$ excretion during the main grazing season within a spring-calving herd.

\section{MATERIALS AND METHODS}

\section{Animal Ethics}

All procedures described in this experiment were approved by the Animal Research Ethics Committee at University College Dublin and conducted under experimental license from the Health Products Regulatory Authority under the European directive 2010/63/EU and S.I. No. 543 of 2012. Each person who carried out procedures on experimental cows during this experiment was authorized to do so by the Health Products Regulatory Authority. Procedures conducted on the experimental cows were deemed mild in severity banding. Hence, no pain, suffering, or distress was observed in experimental cows, and no humane endpoints were required. This experiment was conducted at University College Dublin Lyons Farm, Celbridge, Naas, Co. Kildare, Ireland $\left(53^{\circ} 17^{\prime} 56^{\prime \prime} \mathrm{N}, 6^{\circ} 32^{\prime} 18^{\prime \prime} \mathrm{W}\right)$.

\section{Cows, Treatments, and Experimental Design}

A total of 46 multiparous and 12 primiparous (total 58) Holstein Friesian pasture-based dairy cows were selected from the spring-calving dairy herd at University College Dublin Lyons Farm. Cows were grouped into 2 genotype groups (Table 1): lower milk genotype; $\mathrm{n}$ $=30$ (LM; milk kg PTA: $45 \pm 68.6$; fat kg PTA: 10 \pm 4.9 ; and protein $\mathrm{kg}$ PTA: $7 \pm 2.3)$ and higher milk genotype; $\mathrm{n}=28$ (HM; milk kg PTA: $203 \pm 55.0$; fat $\mathrm{kg}$ PTA: $13 \pm 3.8$; and protein $\mathrm{kg}$ PTA: $10 \pm 2.4)$. The PTA values mentioned herein were a criterion for selection of the 58 cows from a larger herd and contribute to an Irish purpose-made breeding index (Economic Breeding Index; www.icbf.com). Two feeding strategies $[14 \% \mathrm{CP}, \mathrm{n}=30(\mathbf{L C P})$; and $18 \% \mathrm{CP}$, $\mathrm{n}=28$ (HCP) CS; Table 2) were offered at quantities equal to each other, but the quantity of both was varied throughout the study. Levels ranged from 7.9 $\mathrm{kg}$ of $\mathrm{DM} / \mathrm{cow}$ per day at the beginning of the study, eventually decreasing to $3.1 \mathrm{~kg} \mathrm{DM} / \mathrm{cow}$ per day at the end of the study as DIM increased. The reason for the decrease in CS offered to cows as DIM increased was 
because of the decreasing average energy requirement for the herd as milk yields naturally decreased. Cows were randomly assigned to their treatment groups after being blocked on parity and balanced on DIM ( $42 \pm$ 15.2), BCS (at $24 \pm 15.2 \mathrm{DIM}$ ), and overall Economic Breeding Index before commencement of the experiment. Individual cow was considered the experimental unit. For the milk production study, the experiment was a complete randomized block design with a $2 \times 2$ factorial arrangement of the treatments. The feeding strategies were fed over the main grazing season (April 3 to September 3, 2019). For the milk production study, cows within genotype groups were randomly assigned to 1 of 2 feeding strategies, resulting in 4 treatment groups: (1) LM cows fed pasture + LCP $(\mathrm{n}=15)$; (2) LM cows fed pasture + HCP $(\mathrm{n}=15)$; (3) HM cows fed pasture + LCP $(\mathrm{n}=15)$; and (4) HM cows fed pasture $+\mathrm{HCP}(\mathrm{n}=13)$. During the milk production study, a N partitioning study was conducted with 30 cows over a discrete period of 1 wk to investigate differences in NUE between cows offered either LCP ( $\mathrm{n}=$ $15)$ or $\mathrm{HCP}(\mathrm{n}=15)$. At the time of the $\mathrm{N}$ partitioning study $(187 \pm 15.2 \mathrm{DIM})$, cows were offered $3.1 \mathrm{~kg}$ of CS DM/cow per day, and this supplement aided in supplying $100 \%$ of the cows' energy requirements. Cows grazed full time and were offered a basal diet of grazed perennial ryegrass (Lolium perenne L.) pasture (Table 3). Supplementary concentrates were manufactured by Gain Feeds, where all ingredients were ground to form a pellet. Concentrate supplement was dispensed in the milking parlor twice daily; $50 \%$ at a.m. and 50\% at p.m. milking using a Feedrite automatic system linked to cow electronic identification (Dairymaster).

Sample sizes were determined by means of a power test using the coefficient of variation of milk fat yield (Alzahal et al., 2010). Data points where SCC was greater than $3,000,000$ cells $/ \mathrm{mL}$ (2 data points) were removed from the analysis, as these were deemed to be outliers. Sufficient blinding was ensured as the corresponding author was aware of group allocation during the allocation but not during the conduction of the experiment or during the outcome of the data analysis. This eliminated any unconscious bias which may have influenced results.

\section{Data and Sample Collection}

Milk production and NUE parameter measurements were necessary, as they formed part of the study objectives as previously stated.

Cows grazed as a single group and were offered fresh allocations of pasture daily $(14-15 \mathrm{~kg}$ of $\mathrm{DM} / \mathrm{cow}$ total). Cows grazed (to $4 \mathrm{~cm}$ ) together, which eliminated any potential confounding effects such as differences in pasture composition. Pregrazing herbage mass was determined daily before cows entered a new paddock; a total of 50 measurements were taken across each grazing area using a rising plate meter (diameter 355 $\mathrm{mm}$ and $3.2 \mathrm{~kg} / \mathrm{m}^{2}$; Jenquip) by walking in a W-shape across the field. Pregrazing herbage mass averaged $1,284 \mathrm{~kg}$ of DM/ha (above $4 \mathrm{~cm}$ ) for the duration of the study. Postgrazing herbage mass was also measured daily for the duration of the study using a rising plate meter and averaged $127 \mathrm{~kg}$ of DM per ha (above $4 \mathrm{~cm}$ ). Pasture samples were taken pregrazing using a pooled sample of 3 quadrat $\left(0.25 \mathrm{~m}^{2}\right)$ cuts. On a weekly basis, daily pasture samples were pooled for chemical analyses (DM, ether extract, ash, and CP), NDF, ADF, and water-soluble carbohydrates (WSC). Then, monthly changes in pasture quality over the experiment were determined and are shown in Figure 1. Cows had ad libitum access to fresh water.

\section{Milk Sample Collection}

Cows were milked twice daily at $0700 \mathrm{~h}$ and $1500 \mathrm{~h}$. Milk output was recorded and milk sampling was facilitated using the Weighall milk metering and sampling system (Dairymaster). Milk samples for each individual cow were collected and analyzed once per week on the same occasion for milk composition parameters (Doran et al., 2020), thereby controlling any time-related confounding effects. Test day milk fat, total protein, and fat + protein yield were all then determined.

$B W$ and $B C S$. Individual cow BW were measured twice daily using electronic scales as the cows exited the milking parlor through the automatic cow-drafting unit (Dairymaster), and then a weekly average was calculated. Body condition score was assessed by the

Table 1. Genotype profile of cows in the experiment ${ }^{1}$

\begin{tabular}{|c|c|c|c|c|}
\hline Genetic parameter & Lower milk genotype & National percentile & Higher milk genotype & National percentile \\
\hline Milk (kg) & 45 & Top $50 \%$ & 203 & Top $10 \%$ \\
\hline Fat $(\mathrm{kg})$ & 10 & Top $5 \%$ & 13 & Top $1 \%$ \\
\hline Protein (kg) & 7 & Top $10 \%$ & 10 & Top $1 \%$ \\
\hline Fat $(\%)$ & 0.16 & Top $5 \%$ & 0.09 & Top $20 \%$ \\
\hline Protein (\%) & 0.09 & Top $5 \%$ & 0.06 & Top $10 \%$ \\
\hline
\end{tabular}

${ }^{1}$ National percentiles apply to the year 2019. 
Table 2. Chemical composition and ingredient inclusion level of concentrate supplements offered during the 23-wk study

\begin{tabular}{|c|c|c|}
\hline Item & $14 \% \mathrm{CP}$ & $18 \% \mathrm{CP}$ \\
\hline \multicolumn{3}{|l|}{ Chemical composition $(\mathrm{g} / \mathrm{kg})$} \\
\hline DM & 873 & 874 \\
\hline Ash & 81 & 83 \\
\hline $\mathrm{CP}$ & 142 & 181 \\
\hline Starch & 261 & 257 \\
\hline NDF & 218 & 172 \\
\hline $\mathrm{UFL}^{1}$ & 0.99 & 1.00 \\
\hline \multicolumn{3}{|l|}{ Ingredient inclusion level of concentrates ${ }^{2}(\mathrm{~g} / \mathrm{kg})$} \\
\hline Barley & 225 & 217 \\
\hline Maize & 225 & 225 \\
\hline Maize distillers grain with solubles & 100 & 100 \\
\hline Sugar beet pulp pellets, $8 \mathrm{~mm}$ & 150 & 90 \\
\hline Soybean meal, $47 \%$ & 105 & 210 \\
\hline Soy hulls & 87 & 50 \\
\hline Palm oil (mixer) & 9 & 9 \\
\hline Vegetable oil blend (coater) & 6 & 6 \\
\hline Sugarcane molasses (mixer) & 45 & 45 \\
\hline Monocalcium diphosphate & 8 & 8 \\
\hline Calcium carbonate & 8 & 8 \\
\hline Rumen buffer (AcidBuff ${ }^{3}$ ) & 10 & 10 \\
\hline Sodium chloride & 9 & 9 \\
\hline Magnesium oxide & 7.5 & 7.5 \\
\hline Alltech Lifeforce MinPlex Pack ${ }^{4}$ & 0.5 & 0.5 \\
\hline Gain vitamin E $5 \%$ premix & 0.5 & 0.5 \\
\hline B-group vitamin (biotin $2 \%$ premix) & 0.1 & 0.1 \\
\hline Saccharomyces cerevisiae (Yea-Sacc TS 50\% Premix ${ }^{4}$ ) & 0.3 & 0.3 \\
\hline Gain cattle mineral premix & 4 & 4 \\
\hline
\end{tabular}

${ }^{1} \mathrm{UFL}=$ unité fourragère du lait; unit of energy, where $1 \mathrm{UFL}$ is the amount of energy contained in $1 \mathrm{~kg}$ of air-dried barley (87\% DM, 11.2 MJ of ME).

${ }^{2}$ All grains were ground.

${ }^{3}$ Celtic Sea Minerals.

${ }^{4}$ Alltech.

consensus of 2 trained operators following morning milking once every $14 \mathrm{~d}$ using a scale of 1 to 5 with 0.25 increments, according to Edmonson et al. (1989).

Table 3. Chemical composition of the pasture that cows grazed during the 23 -wk study ${ }^{1}$

\begin{tabular}{lrrc}
\hline $\begin{array}{l}\text { Chemical composition } \\
\text { (g/kg of DM unless stated) }\end{array}$ & LSM & SEM & $\begin{array}{c}\text { Month } \\
P \text {-value }\end{array}$ \\
\hline DM (g/kg fresh weight) & 162 & 6.3 & 0.08 \\
Ash & 99 & 3.8 & 0.43 \\
CP & 238 & 11.1 & 0.23 \\
NDF & 442 & 15.3 & 0.08 \\
ADF & 227 & 4.6 & 0.24 \\
Water-soluble carbohydrates & 135 & 11.4 & 0.08 \\
Ether extract & 29 & 2.8 & 0.76 \\
OM digestibility $^{2}$ & 915 & 5.4 & 0.008 \\
PDIN $^{3}$ & 151 & 6.9 & 0.26 \\
PDIE $^{4}$ & 111 & 1.1 & 0.12 \\
PDIA $^{5}$ & 26 & 0.8 & 0.40 \\
\hline
\end{tabular}

${ }^{1}$ All protein truly digested in the small intestine (PDI) values are estimates (INRA, 2010).

${ }^{2} \mathrm{OM}$ digestibility is a predicted value (Kowalski et al., 2014).

${ }^{3} \mathrm{PDIN}=\mathrm{PDI}$, where nitrogen is limiting microbial protein synthesis.

${ }^{4} \mathrm{PDIE}=\mathrm{PDI}$, where energy is limiting microbial protein synthesis.

${ }^{5} \mathrm{PDIA}=$ feed protein truly digested in the small intestine.
Determination of Intake and $N$ Excretion. A $\mathrm{N}$ partitioning study was conducted during wk 22 of the experiment (August 25-30, 2019; $187 \pm 15.2$ DIM). Pasture DMI (PDMI) and N excretion were estimated over a period of $6 \mathrm{~d}$ and determined using the $n$-alkane technique of Dove and Mayes (2006). Cows were dosed with a paper bolus impregnated with $500 \mathrm{mg}$ of the $n$-alkane $n$-dotriacontane for a period of $12 \mathrm{~d}$ following a.m. and p.m. milking. From d 7 to 12, samples of CS, pasture, milk, and feces were collected. Pasture samples were collected in the morning and evening using a quadrat and handheld shears. These samples were immediately dried at $55^{\circ} \mathrm{C}$ for $48 \mathrm{~h}$. Fecal samples were collected whenever possible when cows naturally defecated, and, if not, samples were collected per rectum and placed in a forced-air oven at $55^{\circ} \mathrm{C}$ for $72 \mathrm{~h}$. Samples of milk were collected during a.m. and p.m. milking and pooled according to milk yield daily.

\section{Sample Analyses}

Pasture, Concentrate, and Fecal Sample Analysis. Pasture and concentrate sample analyses 
were conducted by FBA Laboratories (Cappoquin, Waterford, Ireland). Pasture, concentrate, and fecal samples were dried in a forced-air oven at $55^{\circ} \mathrm{C}$ for 48 $\mathrm{h}$ and ground in a hammer mill fitted with a 1-mm screen (Laboratory Mill, Christy Turner Ltd.). The ash content was determined following combustion in a muffle furnace (Nabertherm $\mathrm{GmbH}$ ) at $550^{\circ} \mathrm{C}$ for $5.5 \mathrm{~h}$ (AOAC International, 2005a). The $\mathrm{N}$ content of pasture and fecal samples were determined by combustion on a Leco analyzer, and $\mathrm{CP}$ content was calculated (N $\times 6.25$; FP 528 Analyzer, Leco Corp.; AOAC International, 2005b). The DM content of samples was determined after drying overnight at $105^{\circ} \mathrm{C}(16 \mathrm{~h}$; AOAC International, 2005c). The ether extract of feed samples was determined using a Gerhardt Soxtherm Variostat extraction system. The NDF and ADF contents of feed
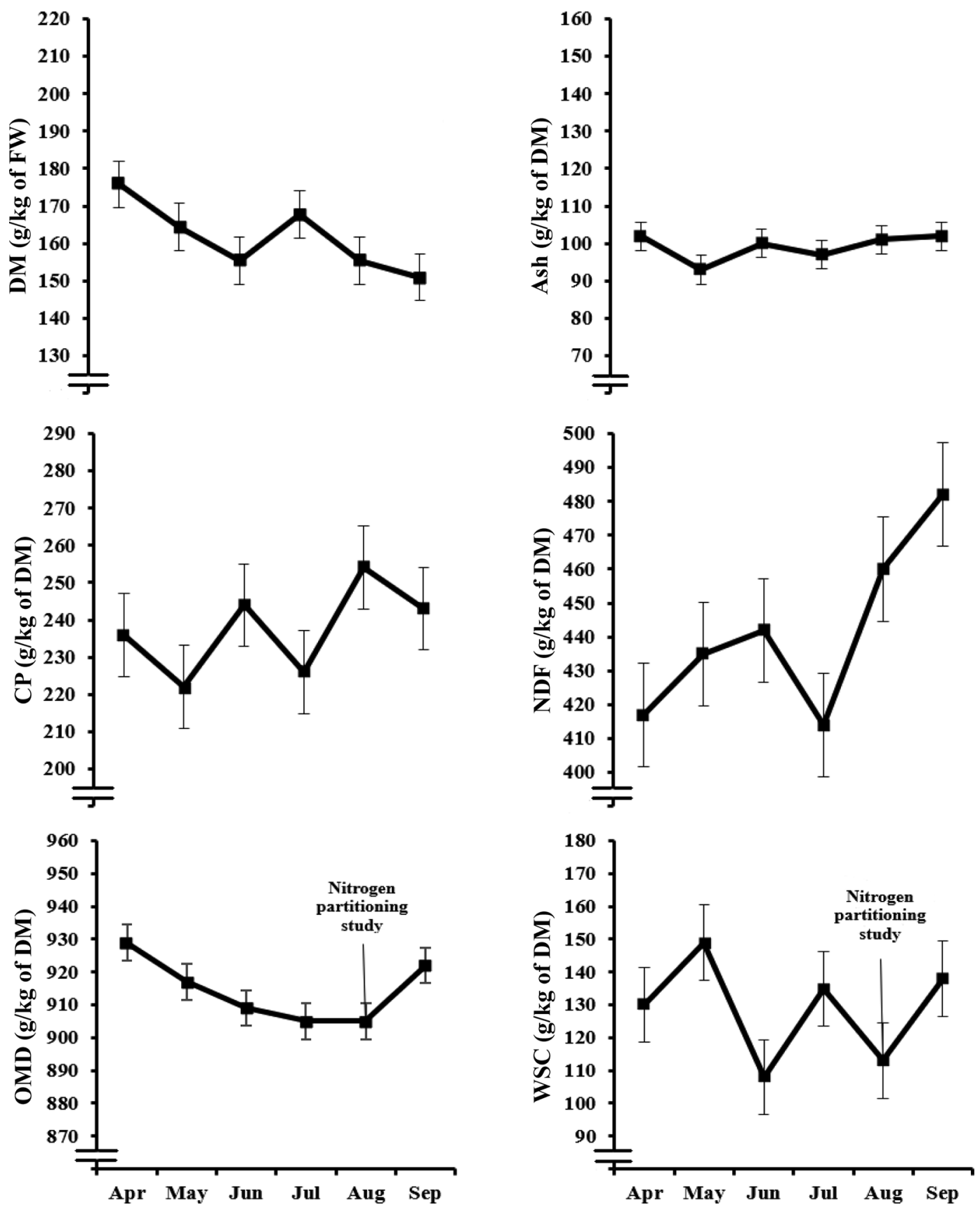

Figure 1. Changes in pasture quality offered to dairy cows during the experiment. FW = fresh weight; OMD = organic matter digestibility; $\mathrm{WSC}=$ water-soluble carbohydrates. Error bars represent SEM. 
samples were determined using the method adapted by Van Soest et al. (1991) for use in the Ankom 220 Fiber Analyzer (Ankom Technology). This method includes a thermostable $\alpha$-amylase and $20 \mathrm{~g}$ of sodium sulfide, but residual ash was not determined. The WSC were measured by spectrophotometry using a Genesys 150 UV-Visible Spectrophotometer.

Milk Sample Analysis. Concentrations of milk fat, total protein, and SCC were determined in a commercial milk laboratory (National Milk Laboratories Ltd., Wolverhampton, UK) using mid-infrared spectrometry (MilkoScan FT6000, Foss Analytical A/S; Soyeurt et al., 2006). Values for ECM and FCM to $40 \mathrm{~g} / \mathrm{kg}$ were calculated as follows: $\mathrm{ECM}=[(0.327 \times$ milk yield $\mathrm{kg})$ $+(7.2 \times$ milk protein $\mathrm{kg})+(12.95 \times$ milk fat $\mathrm{kg})]$ (Eslamizad et al., 2010); and $40 \mathrm{~g} / \mathrm{kg}$ of $\mathrm{FCM}=[(0.4$ $\times$ milk yield $\mathrm{kg})+(15 \times$ fat yield $\mathrm{kg})$ ] (Gaines and Davidson, 1923).

\section{Nitrogen Partitioning Study}

Pasture DMI was determined by extracting $n$-alkanes from feed and feces samples according to the method of Dove and Mayes (2006). Following extraction, samples were analyzed for concentrations of $n$-alkanes by gas chromatography using a Scion 456-GC (Scion Instruments) fitted with a 30-m capillary column with an internal diameter of $0.53 \mathrm{~mm}$ coated with $1.5 \mu \mathrm{m}$ of dimethyl polysiloxane (Agilent Technologies Ireland Ltd.). These data were then applied to the following equation to calculate $\mathrm{PDMI} / \mathrm{cow}$ per day (Mayes et al., 1986): PDMI $=[(F i / F j)(D j+I c C j)-I c C i] /[H i-(F i /$ $F j H j)$ ], where $F i$ and $F j$ are the concentrations of naturally occurring odd-chain (feed-derived) and even-chain (dosed $n$-dotriacontane) $n$-alkane in feces, respectively $(\mathrm{mg} / \mathrm{kg}) ; H i$ and $H j$ are the concentrations of natural odd-chain and even-chain $n$-alkanes in pasture, respectively $(\mathrm{mg} / \mathrm{kg}) ; D j$ is the daily dose rate of the evenchain $n$-alkanes $(\mathrm{mg} / \mathrm{kg}) ; I c$ is the daily concentrate intake $(\mathrm{kg} / \mathrm{d})$; and $C i$ and $C j$ are the concentrations of natural odd-chain and even-chain $n$-alkanes in concentrate feed $(\mathrm{mg} / \mathrm{kg})$, respectively. Nitrogen partitioning was then calculated according to Whelan et al. (2012) as follows: $\mathrm{N}$ intake $(\mathrm{g})=[(\mathrm{kg}$ of PDMI $\times \mathrm{g} \mathrm{N} / \mathrm{kg}$ of $\mathrm{DM}$ pasture $)+(\mathrm{kg}$ of concentrate $\mathrm{DMI} \times \mathrm{g}$ of $\mathrm{N} / \mathrm{kg}$ of DM concentrate)]; Fecal $\mathrm{N}(\mathrm{g})=(\mathrm{kg}$ of fecal DM excretion $\times \mathrm{g}$ of $\mathrm{N} / \mathrm{kg}$ of $\mathrm{DM}$ feces $)$; milk $\mathrm{N}=(\mathrm{kg}$ of milk yield $\times \mathrm{g}$ of $\mathrm{N} / \mathrm{kg}$ of milk); and urine $\mathrm{N}(\mathrm{g})=[\mathrm{N}$ intake $(\mathrm{g})$ - fecal N (g) - milk N (g)]. Fecal output was determined according to the method of Dove and Mayes (2006). These data were then applied to the following equation to determine $\mathrm{DM}$ digestibility: DM digestibility $=[(A j-K b) / A j]$, where $A j$ is the PDMI and $K b$ is fecal output ( $\mathrm{kg}$ of $\mathrm{DM})$.

\section{Statistical Analysis}

Data points for all parameters were closely observed during the analysis. If data points were deemed to be biologically impossible or extreme outliers, these data points were removed from the analysis. Residuals of data were assessed for normality and homogeneity of variance by histograms, QQ-plots, and formal statistical tests as part of the UNIVARIATE procedure of SAS (version 9.4; SAS Institute Inc.). Non-normal data were transformed by raising the variable to the power of lambda. The appropriate lambda value was obtained by conducting a Box-Cox transformation analysis using the TRANSREG procedure of SAS (Fahey et al., 2007). The transformed data were used to calculate $P$-values. The corresponding least squares means and standard error of the untransformed data are presented in the results for clarity. The relationships between milk $\mathrm{N}$ output, urine $\mathrm{N}$ excretion, and feces $\mathrm{N}$ excretion were tested for associations using the CORR procedure of SAS. Data were analyzed using the repeated-measures function MIXED procedure of SAS (milk production, milk composition, BW, BCS, NUE, and pasture quality). The fixed effects in the model included treatments (supplement CP concentration; LCP vs. HCP, genotype; LM vs. HM, and time) and their interactions. Week of experiment was the repeated unit, and cow was the random effect. Interactions were removed from fixed effects where $P>0.10$. Heterogeneous compound symmetry, unstructured, autoregressive, heterogeneous first-order autoregressive, Toeplitz, and heterogeneous Toeplitz were the variance and covariance structures considered. The model with the lowest Bayesian information criterion value was selected. Differences between means were determined by $F$-tests using type III sums of squares. A probability of $P<0.05$ was selected as the level of significance, and statistical tendencies were reported when $P \geq 0.05$ but $<0.10$.

\section{RESULTS}

\section{Milk Production and Milk Composition}

No interaction $(P>0.10)$ was observed for any milk production or milk compositional parameter measured. Therefore, the results will focus on the main effects of supplement $\mathrm{CP}$ concentration and cow genotype on milk production and milk composition.

The effects of supplement CP concentration and cow genotype on milk production and milk composition are shown in Table 4. No differences were observed for milk yield, fat $\mathrm{kg}$, protein $\mathrm{kg}$, and fat + protein $\mathrm{kg}$ $(P>0.10)$ between cows offered LCP and HCP. The HM cows tended $(P=0.08)$ to have increased trial 
Table 4. Effects of supplement CP concentration and cow genotype on milk production and milk composition for the 23 -wk study ${ }^{1}$

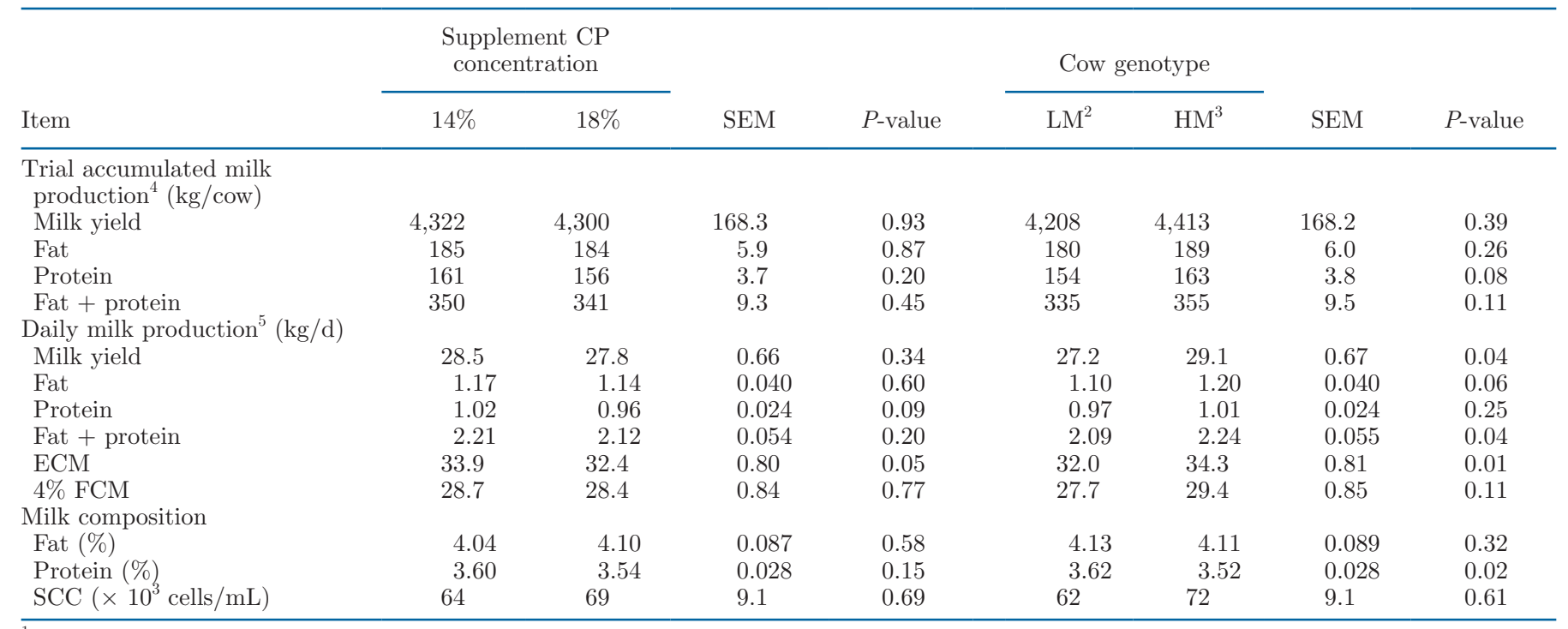

\footnotetext{
${ }^{2}$ Lower milk genotype cows.

${ }^{3}$ Higher milk genotype cows.

${ }^{4}$ Total accumulated milk production per cow from start to end of experiment.

${ }^{5}$ Average milk production per cow per day from start to end of experiment.
}

${ }^{1}$ No interaction occurred between CP concentration and genotype, and no interaction occurred between treatment and time.

accumulated milk protein $\mathrm{kg}$ compared with LM cows. Cows offered LCP tended to have increased daily milk protein $\mathrm{kg}(P=0.09)$ and $\mathrm{ECM}(P=0.05)$ compared with cows offered HCP. The HM cows had increased daily milk yield $(P=0.04)$, fat + protein $\mathrm{kg}(P=$ $0.04)$, and ECM yield $(P=0.03)$ compared with LM cows, whereas HM cows tended $(P=0.06)$ to have increased daily milk fat $\mathrm{kg}$ compared with LM cows. No differences were observed for any milk composition parameter (milk fat, protein, fat:protein ratio, and SCC; $P>0.10)$ measured between cows offered LCP and HCP. The HM cows had decreased $(P=0.02)$ milk protein concentration compared with LM cows.

\section{DMI and Nitrogen Partitioning}

The effects of supplement CP concentration on DMI and $\mathrm{N}$ partitioning are shown in Table 5 . Cows offered LCP had increased PDMI $(P<0.0001)$ and total DMI (TDMI; $P<0.0001)$ compared with cows offered HCP. No differences $(P>0.10)$ were observed for TDMI per kilogram of cow BW or total BW between cows offered LCP and HCP. Cows offered LCP had a decreased $(P<0.001)$ overall dietary $\mathrm{CP}$ content compared with cows offered HCP. Cows offered LCP had increased pasture $\mathrm{N}$ intake $(P<0.0001)$ and total feed $\mathrm{N}$ intake $(P=0.0004)$ compared with cows offered HCP. Furthermore, cows offered LCP had increased $(P$ $=0.01)$ fecal $\mathrm{N}$ excretion compared with cows offered HCP. Cows offered LCP had a decreased $(P=0.03)$ proportion of $\mathrm{N}$ excreted in milk and tended $(P=0.09)$ to have an increased proportion of $\mathrm{N}$ excreted in the feces compared with cows offered HCP. Furthermore, cows offered LCP excreted a greater proportion $(P=$ 0.03 ) of their total feed $\mathrm{N}$ intake compared with cows offered HCP, resulting in cows offered LCP having decreased $(P=0.03)$ NUE compared with cows offered $\mathrm{HCP}$.

We found negative linear relationships (Figures 2 and 3) between fecal $\mathrm{N}$ excretion and urinary $\mathrm{N}$ excretion (Equation [1]; $P=0.01 ; \mathrm{R}^{2}=0.21$ ), and between milk $\mathrm{N}$ output and urinary $\mathrm{N}$ excretion (Equation [2]; $P<$ $\left.0.001 ; \mathrm{R}^{2}=0.59\right)$, respectively:

$$
\begin{aligned}
& \text { Urinary N excretion }(\mathrm{kg} / \mathrm{d})=-0.905( \pm 0.3298) \\
& \times \text { feces N excretion }(\mathrm{kg} / \mathrm{d})+0.416( \pm 0.0370) ; \quad[1] \\
& \text { Urinary N excretion }(\mathrm{kg} / \mathrm{d})=-0.977( \pm 0.1494) \\
& \times \text { milk N output }(\mathrm{kg} / \mathrm{d})+0.437( \pm 0.0189) . \quad[2] \\
& \text { DISCUSSION }
\end{aligned}
$$

\section{DISCUSSION}

There is a focus on decreasing the dietary $\mathrm{N}$ intake to reduce environmental $\mathrm{N}$ excretion due to the detrimental impact of $\mathrm{N}$ on water quality (Tamminga, 1992; EPA, 2017). Both supplementary concentrates used in this study are typical of what is commonly used on commercial Irish dairy farms. 
Table 5. Effect of supplement CP concentration on DMI and nitrogen partitioning during wk 22 of the study

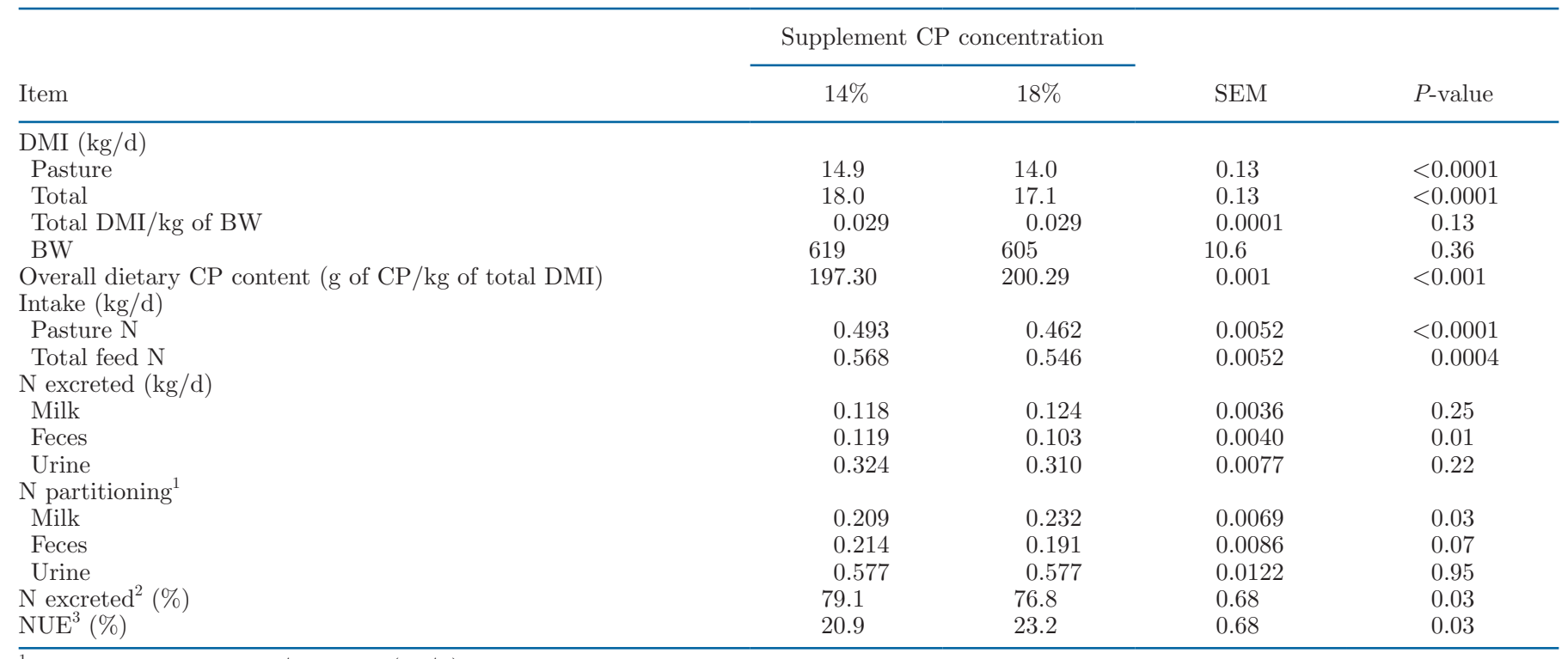

${ }^{1} \mathrm{~N}$ partitioning $=\mathrm{N}$ out $/ \mathrm{N}$ intake $(\mathrm{kg} / \mathrm{d})$.

${ }^{2} \mathrm{~N}$ excreted, $\%=\mathrm{N}$ out $\{[$ feces + urine output $(\mathrm{kg} / \mathrm{d})] / \mathrm{N}$ intake $(\mathrm{kg} / \mathrm{d})\} \times 100$.

${ }^{3} \mathrm{~N}$ utilization efficiency $=\mathrm{N}$ out $\{[$ milk output $(\mathrm{kg} / \mathrm{d})] / \mathrm{N}$ intake $(\mathrm{kg} / \mathrm{d})\} \times 100$.

\section{Milk Production and Milk Composition}

Despite the differences in PDMI and TDMI observed between cows offered different supplement $\mathrm{CP}$ concentrations during wk 22 of the study, trial accumulated or daily average milk production were not affected by supplement CP concentration. It is important to note that PDMI and TDMI differences were representative of $1 \mathrm{wk}$ only, when cows were in late lactation, and may not accurately reflect daily intake predictions for the entire milk production study. Therefore, offering cows the decreased supplement CP level of $14 \%$ may have been sufficient to support levels of milk production similar to offering cows the increased level of $18 \%$ supplement CP during the main grazing season. Given the increasing focus on decreasing supplement CP levels because of environmental concerns (Tamminga, 1992), this would be an important finding. Compared with our findings, Hynes et al. (2016) showed that decreasing the supplement CP concentration from 181 to $141 \mathrm{~g}$ of $\mathrm{CP} / \mathrm{kg}$ of $\mathrm{DM}$ did not decrease milk production when cows were fed pasture $(183 \mathrm{~g}$ of $\mathrm{CP} / \mathrm{kg}$ of $\mathrm{DM}, 461 \mathrm{~g}$ of $\mathrm{NDF} / \mathrm{kg}$ of DM, and $162 \mathrm{~g}$ of WSC/kg of DM). However, the pasture in our study had increased CP (236 g of $\mathrm{CP} / \mathrm{kg}$ of DM), decreased NDF (434 g of NDF $/ \mathrm{kg}$ of $\mathrm{DM})$, and decreased WSC (134 g of WSC $/ \mathrm{kg}$ of DM). Furthermore, in Hynes et al. (2016), decreasing the supplement CP did not affect voluntary DMI or milk production. This is compelling enough evidence to suggest that if DMI values remained similar in our study, milk production would still be similar between treatments. However, cows in the above study were housed and fed fresh-cut pasture, whereas our cows grazed outdoors for the duration of the study. This difference is important, as the study of Dohme-Meier et al. (2014) found that grazing dairy cows expended energy differently than cows that were brought fresh-cut pasture. Additionally, the study of Hynes et al. (2016) was not as long in duration as our study. Although the overall dietary CP content of the treatments differed between cows offered LCP and HCP (197.30 vs. $200.29 \mathrm{~g}$ of CP/ $\mathrm{kg}$ of TDMI) during the $\mathrm{N}$ partitioning period in our study, cows offered LCP were still overfed dietary CP. Broderick (2003) showed that increases in dietary CP above $167 \mathrm{~g}$ of $\mathrm{CP} / \mathrm{kg}$ of TDMI had no positive effects on milk yield, fat $\mathrm{kg}$, or protein $\mathrm{kg}$; hence, we would not have observed decreases in milk production with offering LCP even if intakes were similar in our findings. However, an important caveat of using the study of Broderick (2003) as a benchmark for maximum dietary $\mathrm{CP}$ concentrations is that the study was conducted on TMR diets. Therefore, benchmarks in Broderick (2003) may or may not apply to studies where fresh forages are offered to cows. Elsewhere, Mulligan et al. (2004) and Burke et al. (2008) compared a 90 to a $240 \mathrm{~g} \mathrm{CP} /$ $\mathrm{kg}$ DM CS and a 69 to a $194 \mathrm{~g} \mathrm{CP} / \mathrm{kg}$ DM in early and mid-lactation, respectively. Decreasing the supplement $\mathrm{CP}$ concentration did not decrease milk yield, fat $\mathrm{kg}$, or protein $\mathrm{kg}$ in these studies. However, these were shorter-term studies than ours. Further research should 
focus on reducing the CS CP content below the levels offered in our study. This may provide more clarity on optimum lower levels of supplemental CP for grazing dairy cows over the main grazing season.

No interaction was found between genotype and supplement $\mathrm{CP}$ for any milk production parameter; however, HM cows had increased daily milk yield, fat + protein $\mathrm{kg}$, and ECM yield, which is in agreement with Ferris et al. (1999) and Kennedy et al. (2003). An increased ECM yield could be the result of an increased feed efficiency, as these two variables have previously been positively correlated with each other (Gami et al., 2018). Furthermore, Coleman et al. (2010) showed that feed efficiencies could differ between differing cow genotypes within the Holstein Friesian breed, although milk PTA figures were not reported. Despite the observed increase in daily milk fat + protein $\mathrm{kg}$ with $\mathrm{HM}$ cows, we observed no differences in trial accumulated milk fat + protein $\mathrm{kg}$ between cow genotypes in our study. This result is consistent with the findings of O'Sullivan et al. (2019), whose cows also differed in their milk production PTA. Elite cows had a milk kg PTA of $-52.0 \pm$ 132.6, a fat $\mathrm{kg}$ of $6.9 \pm 5.08$, and a protein $\mathrm{kg}$ PTA of $2.5 \pm 3.73$, whereas national average cows had a milk $\mathrm{kg}$ PTA of $0.6 \pm 127.4$, a fat $\mathrm{kg}$ PTA of $3.4 \pm 4.15$, and a protein $\mathrm{kg}$ PTA of $0.5 \pm 3.42$ in the aforementioned study. The lack of difference in trial accumulated milk fat + protein $\mathrm{kg}$ in our findings could be attributed to milk, fat, and protein kg PTA differences between cow genotypes. Differences in PTA between genotypes may not have been sufficient to detect trial accumulated milk production differences during our 23-wk study. Alternatively, milk production PTA values for genotypes in our study were 305-d predicted values, but the experiment was conducted for $161 \mathrm{~d}$ (42-203 DIM). Therefore, it is more likely that our experiment would have found differences in trial accumulated milk production between cow genotypes if whole-lactation milk production data were obtained (1-42 DIM and 203-305 DIM included).

\section{DMI and Nitrogen Partitioning}

When using the method of Whelan et al. (2012) to calculate $\mathrm{N}$ partitioning, it was assumed that negligible levels of $\mathrm{N}$ were retained in the cow. This is a valid assumption considering that cow BW did not change from the start to the end of that experiment. As cow BW did not change from the start to the end of our experiment (Figure 4), this assumption also applies to our experiment. Additionally, Steinshamn et al. (2006), Mulligan et al. (2004), and Whelan et al. (2012) calcu-

\section{LCP — HCP A}

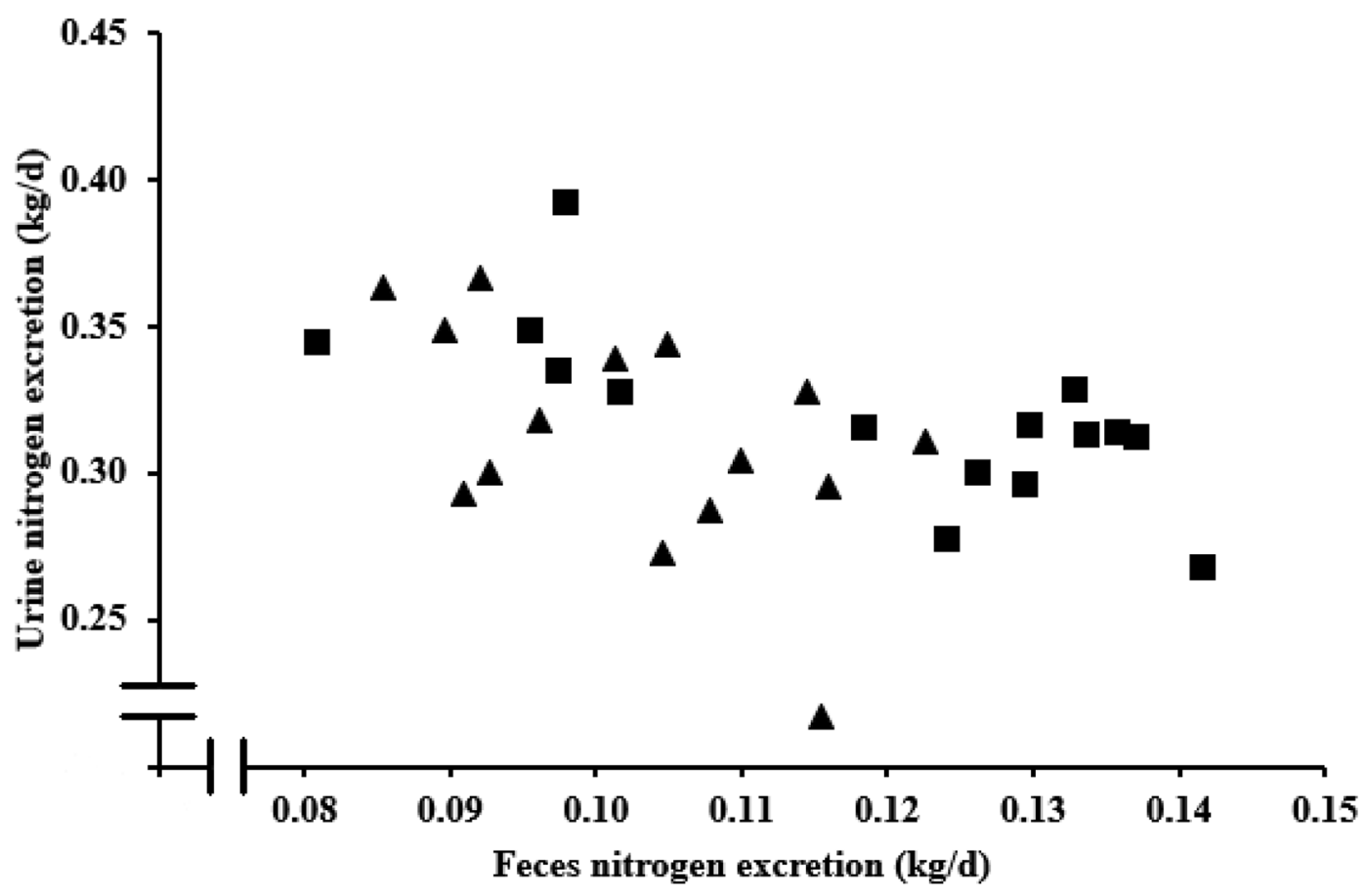

Figure 2. Pattern of estimated urinary $\mathrm{N}$ excretion plotted over the range of feces $\mathrm{N}$ excretion observed for cows. Urine $\mathrm{N}$ was estimated by a difference calculation, as stated in the text. LCP = cows offered the lower CP supplement $(\mathbf{\square})$; HCP = cows offered the higher CP supplement $(\mathbf{\Lambda})$. 


\section{LCPE HCPA}

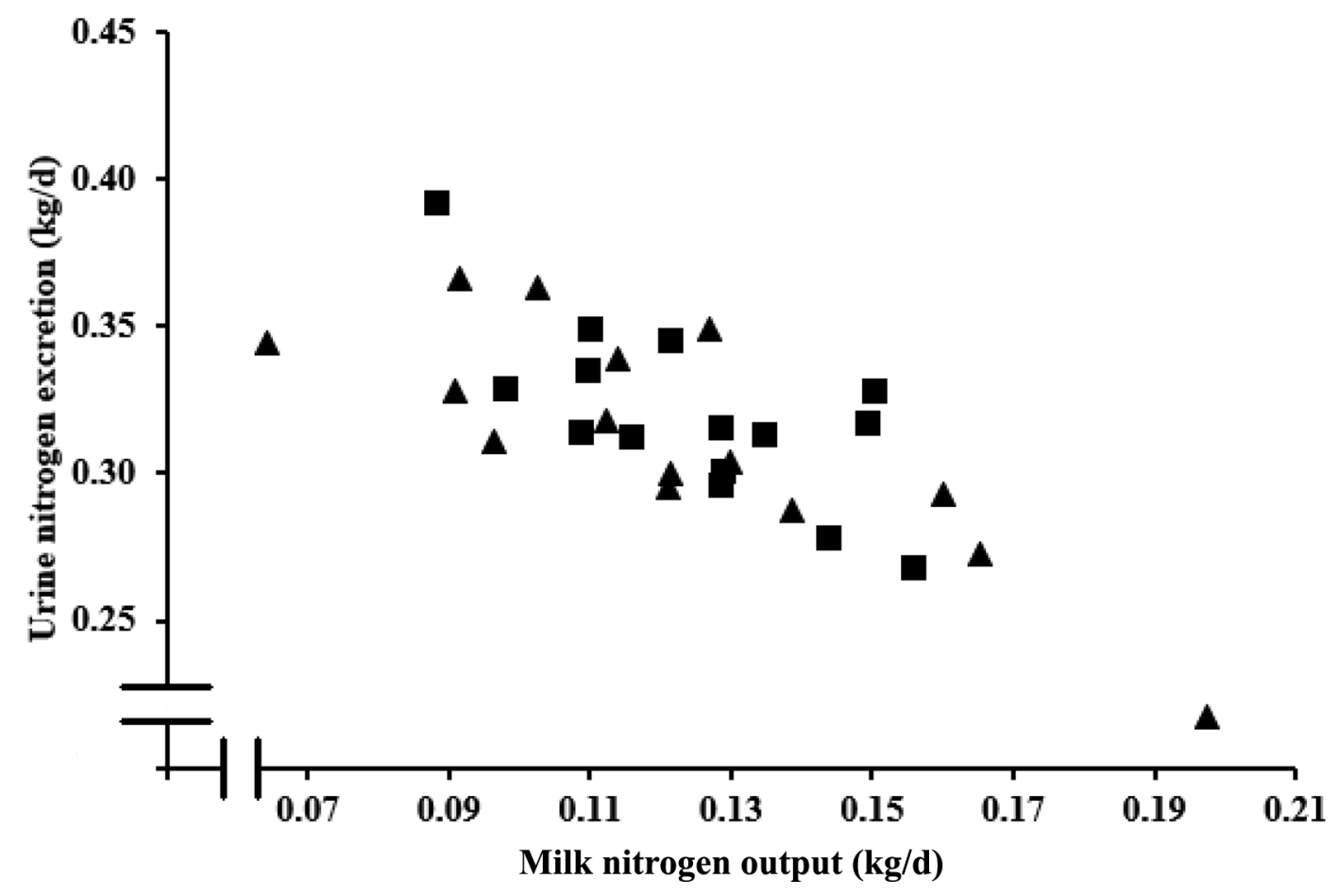

Figure 3. Pattern of estimated urinary $\mathrm{N}$ excretion plotted over the range of milk $\mathrm{N}$ output observed for cows. Urine $\mathrm{N}$ was estimated by a difference calculation, as stated in the text. LCP = cows offered the lower CP supplement $(\mathbf{\square})$; HCP = cows offered the higher CP supplement $(\boldsymbol{\Lambda})$.

lated $\mathrm{N}$ intake and fecal $\mathrm{N}$ with $n$-alkane markers while calculating urine $\mathrm{N}$ by difference. Our N partitioning study was conducted once in $23 \mathrm{wk}$, and the aim of this was to provide a snapshot in time to investigate potential differences between treatments. Cows were, on average, 187 DIM at the start of the N partitioning study, and this coincides with cows advancing in lactation stage. Castillo (2001) elucidated that dairy cow NUE decreases as DIM increases. Therefore, a N partitioning study was conducted later in the study (wk 22) to investigate potential differences between treatments at a time when NUE becomes problematic in grazing herds.

Previous studies show that altering the supplement CP concentration does not affect PDMI or TDMI (Burke et al., 2008; Whelan et al., 2012; Hynes et al., 2016). Despite this phenomenon, cows in our study that were offered LCP had increased PDMI and, consequently, TDMI, even though LCP and HCP supplements were supplied in equal quantities. Dry matter intake has previously been positively correlated with cow BW (Vazquez and Smith, 2000). We found a numerical difference in cow BW between cows offered LCP and HCP during the N partitioning period reported herein, and this may have contributed to the PDMI difference between LCP and HCP treatments. Furthermore, when TDMI was expressed on a per kilogram of cow BW basis, we observed no differences in TDMI between cows offered LCP or HCP. The LSM of TDMI per kilogram of BW obtained for cows offered LCP and HCP in this study were similar to the LSM obtained in the studies of Prendiville et al. (2010) and Coleman et al. (2010), wherein cows grazed pasture.

Previous studies have demonstrated that increasing the supplement or dietary CP concentration has augmented levels of total dietary $\mathrm{N}$ intake in dairy cows (Mulligan et al., 2004; Whelan et al., 2012; Barros et al., 2017). Contradictory to these findings, cows offered LCP had an increased total dietary $\mathrm{N}$ intake compared with cows offered HCP in our study. We can attribute this result to the fact that cows offered LCP had an increased PDMI compared with cows offered HCP. Contrary to other research (Burke et al., 2008; Whelan et al., 2012; Reid et al., 2015b), the increase in total dietary $\mathrm{N}$ intake did not result in an increase in urinary $\mathrm{N}$ excretion but saw an increase in fecal $\mathrm{N}$ excretion. Despite this unusual result, it is important to note that these N partitioning and DMI results were represen- 
tative of a single week only during the experimental period as cows were advancing in lactation stage, and that these results may not reflect happenings of the entire experiment. This is because OM digestibility of the diet is known to be positively related to fecal $\mathrm{N}$ excretion (Lukas et al., 2005). Pasture OM digestibility (in vitro) fluctuated with time in this experiment (Table 3 and Figure 1), which could mean that fecal N levels may also have fluctuated with time. Therefore, further research should focus on milk production over a similar period but also focus on $\mathrm{N}$ partitioning when cows are in early and mid-lactation. This would provide researchers with a broader picture of $\mathrm{N}$ partitioning across an entire lactation when cows are pasture-based and would complement our research.

Upon analysis, we found no linear relationship between dietary $\mathrm{N}$ intake and urinary $\mathrm{N}$ excretion, which explains why urinary $\mathrm{N}$ excretion was not increased with increasing feed $\mathrm{N}$ intake in our findings. The aforementioned studies that have found increases in urinary $\mathrm{N}$ excretion with increasing total dietary $\mathrm{N}$ intake had a larger range of total feed $\mathrm{N}$ intakes compared with the range in our findings (from 546-568 g). Total feed $\mathrm{N}$ intakes ranged from 561 to $654 \mathrm{~g}$ of $\mathrm{N}$ in Burke et al. (2008), from 473 to $545 \mathrm{~g}$ of $\mathrm{N}$ in Whelan et al. (2012), and from 665 to $744 \mathrm{~g}$ in Reid et al. (2015b). Therefore, the total dietary $\mathrm{N}$ intake range between treatments in our findings may not have been sufficient to detect a relationship between urinary $\mathrm{N}$ excretion and total dietary $\mathrm{N}$ intake. Additionally, cows offered LCP had decreased NUE. This result was supported by the fact that cows in this treatment had no improvement in milk $\mathrm{N}$ output despite the increase in total dietary $\mathrm{N}$ intake that was associated with increased PDMI. It is important to consider that $\mathrm{N}$ partitioning results observed herein could be somewhat attributed to the PDMI difference between cows offered either LCP or HCP. Furthermore, NUE for treatments ranged from 20.9 to $23.2 \%$ in our findings. This range is lower than the range reported in the study of Hynes et al. (2016; 27.1-27.4\%). The lower cow-level NUE range observed in our study may have been due to the higher overall dietary CP concentration (198.8 $\mathrm{g}$ of $\mathrm{CP} / \mathrm{kg}$ of TDMI) compared with Hynes et al. (2016) (results indicate $<180 \mathrm{~g}$ of $\mathrm{CP} / \mathrm{kg}$ of TDMI, given the total $\mathrm{N}$ intake as a percentage of TDMI). Lee et al. (2011) showed that increasing dietary $\mathrm{CP}$ concentration corresponds to lower cow-level NUE. Alternatively, the difference in reported NUE between our findings and the study of Hynes et al. (2016) may have been due to the differ-

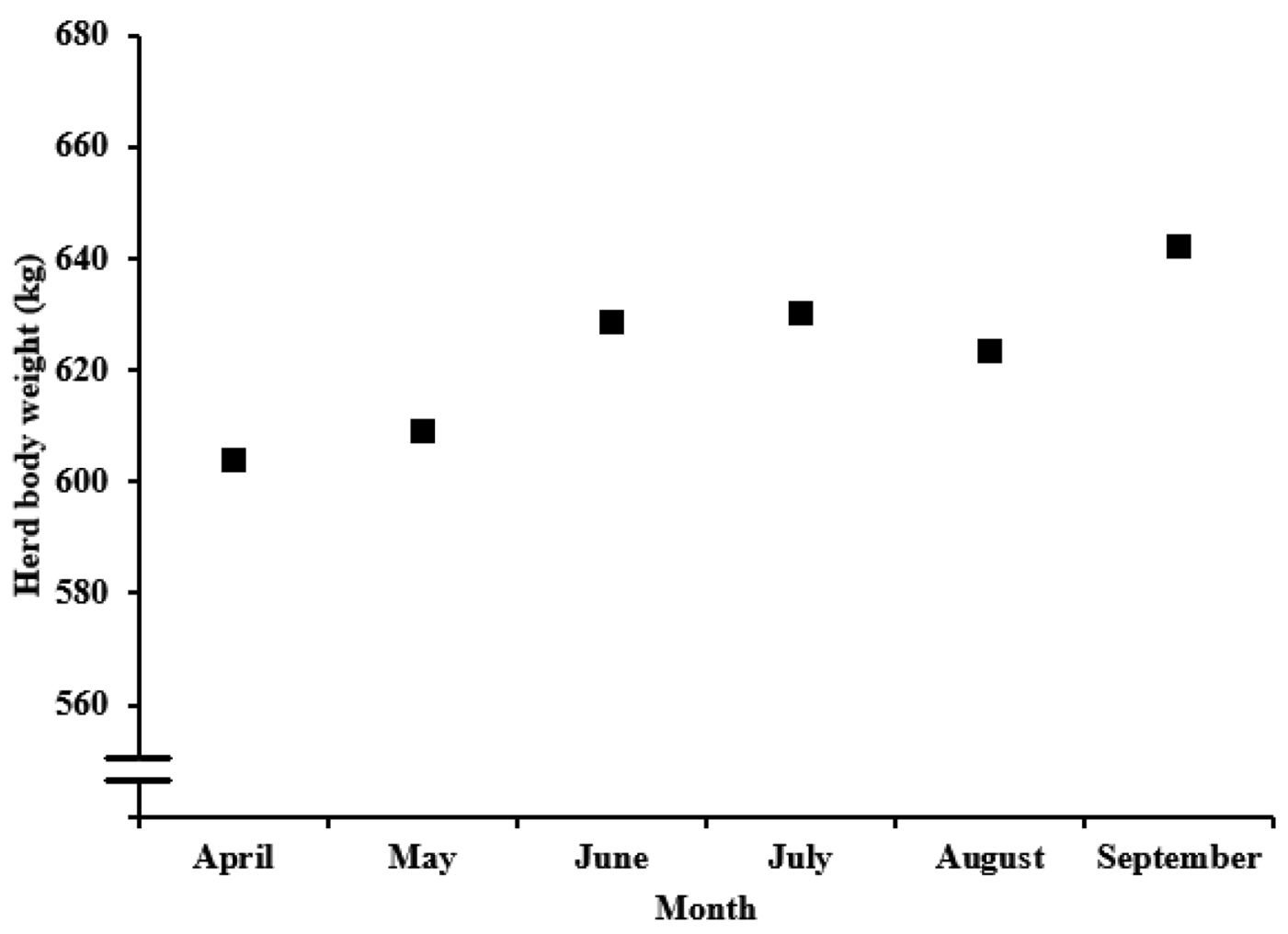

Figure 4. Herd BW change over the range of time $(P=0.16)$. 
ing ratio of pasture WSC to $\mathrm{CP}$ (Keim and Anrique, 2011; Parsons et al., 2011). The larger ratio for the N partitioning study in our findings (calculated as $\mathrm{CP} \%$ / $\mathrm{WSC} \% ; 2.1)$ compared with the ratio in the findings of Hynes et al. $(2016 ; 1.1)$ may explain why the NUE of cows in our study was lower than that of cows in Hynes et al. (2016). The studies of Keim and Anrique (2011) and Parsons et al. (2011) highlight the importance of pasture nutrient interactions on dairy cow NUE.

As demonstrated by Equation [1], we found a negative linear relationship between fecal $\mathrm{N}$ excretion and urinary $\mathrm{N}$ excretion; where fecal $\mathrm{N}$ excretion was increased, urinary $\mathrm{N}$ excretion was simultaneously decreased. The literature shows that increasing the amount of ingested $\mathrm{N}$ excreted as fecal $\mathrm{N}$, instead of urinary $\mathrm{N}$, has environmental significance, primarily because of the reduction of $\mathrm{N}$ loss as $\mathrm{N}_{2} \mathrm{O}$ (Tamminga, 1992) and $\mathrm{NH}_{3}$ (Bussink and Oenema, 1998). Similarly, we observed a negative linear relationship between milk $\mathrm{N}$ output and urinary $\mathrm{N}$ excretion (Equation [2]). An increase in milk $\mathrm{N}$ output simultaneously led to a decrease in urinary $\mathrm{N}$ excretion. This is an important result, not only in terms of environmental benefits but also for the economics of milk production. The study of Cheng et al. (2014) showed that achieving an increase in milk $\mathrm{N}$ output through genetic improvement is possible, although only numerical decreases in urine $\mathrm{N}$ excretion were concurrently observed in that study. This strengthens the requirement for further research to be conducted on $\mathrm{N}$ partitioning where cows differ in their milk production PTA.

\section{CONCLUSIONS}

This study shows that it may be possible to reduce supplement CP concentration without negatively influencing accumulated milk fat + protein yield during the main grazing season. However, any potential negative effect of offering LCP on milk production may have been offset by the increased PDMI. Similarly, the decreased NUE associated with offering cows the LCP supplement could be attributed to an increase in $\mathrm{N}$ intake, whereas no such increases were observed for milk $\mathrm{N}$ output. The results of this experiment would be important for milk producers, considering that lower-protein concentrates are now a requirement for many grazing livestock farmers, to comply with the EU Nitrates Directive. Further research should focus on investigating (1) whether supplement CP concentration can be successfully reduced to levels lower than those investigated in this study without affecting milk production, and (2) whether improved milk production through selection for fat and protein yield PTA influ- ences feed efficiency and NUE during the main grazing season where pasture-based systems are practiced.

\section{ACKNOWLEDGMENTS}

Funding for this research was provided under the Innovative Dairy Production Systems and Technologies (Dairy Tech) project through the Enterprise Ireland Innovation Partnership Programme (Dublin, Ireland), which is co-funded by the EU through the European Regional Development Fund 2014-2020. Additionally, the authors acknowledge the contributions of the laboratory and farm staff and students at University College Dublin Lyons Farm. The authors have not stated any conflicts of interest.

\section{REFERENCES}

Alzahal, O., M. M. Or-Rashid, S. L. Greenwood, and B. W. McBride. 2010. Effect of subacute ruminal acidosis on milk fat concentration, yield and fatty acid profile of dairy cows receiving soybean oil. J. Dairy Res. 77:376-384. https://doi.org/10.1017/ S0022029910000294.

AOAC International. 2005a. Ash in animal feed, method number 942.05. Official Methods of Analysis. 18th ed. AOAC International.

AOAC International. 2005b. Crude protein in animal feed, method number 990.03. Official Methods of Analysis. 18th ed. AOAC International.

AOAC International. 2005c. Moisture in animal feed, method number 960.15. Official Methods of Analysis. 18th ed. AOAC International.

Bargo, F., L. D. Muller, E. S. Kolver, and J. E. Delahoy. 2003. Invited review: Production and digestion of supplemented dairy cows on pasture. J. Dairy Sci. 86:1-42. https://doi.org/10.3168/jds.S0022 -0302(03)73581-4.

Barros, T., M. Quaassdorff, M. Aguerre, J. O. Colmenero, S. Bertics, P. Crump, and M. Wattiaux. 2017. Effects of dietary crude protein concentration on late-lactation dairy cow performance and indicators of nitrogen utilization. J. Dairy Sci. 100:5434-5448. https:// doi.org/10.3168/jds.2016-11917.

Berry, D. P. 2013. Breeding strategies to reduce environmental footprint in dairy cattle. Adv. Anim. Biosci. 4(Suppl. 1):28-36. https: //doi.org/10.1017/S2040470013000289.

Broderick, G. A. 2003. Effects of varying dietary protein and energy levels on the production of lactating dairy cows. J. Dairy Sci. 86:1370-1381. https://doi.org/10.3168/jds.S0022-0302(03)73721 -7 .

Burke, F., M. O'Donovan, J. Murphy, F. O'Mara, and F. Mulligan. 2008. Effect of pasture allowance and supplementation with maize silage and concentrates differing in crude protein concentration on milk production and nitrogen excretion by dairy cows. Livest. Sci. 114:325-335. https://doi.org/10.1016/j.livsci.2007.05.019.

Bussink, D., and O. Oenema. 1998. Ammonia volatilization from dairy farming systems in temperate areas: A review. Nutr. Cycl. Agroecosyst. 51:19-33. https://doi.org/10.1023/A:1009747109538.

Casey, J., and N. Holden. 2005. Analysis of greenhouse gas emissions from the average Irish milk production system. Agric. Syst. 86:97114. https://doi.org/10.1016/j.agsy.2004.09.006.

Castillo, A. 2001. Improving nitrogen utilisation in dairy cows. PhD Thesis. University of Reading, UK.

Cheng, L., S. Woodward, R. Dewhurst, H. Zhou, and G. Edwards. 2014. Nitrogen partitioning, energy use efficiency and isotopic fractionation measurements from cows differing in genetic merit fed low-quality pasture in late lactation. Anim. Prod. Sci. 54:16511656. https://doi.org/10.1071/AN14171. 
Coleman, J., D. Berry, K. Pierce, A. Brennan, and B. Horan. 2010. Dry matter intake and feed efficiency profiles of 3 genotypes of Holstein-Friesian within pasture-based systems of milk production. J. Dairy Sci. 93:4318-4331. https://doi.org/10.3168/jds.2009-2686.

DAFM. 2021. 2021 Nitrates Derogation: Terms and Conditions. Accessed May 19, 2021. https://assets.gov.ie/119723/f10e2498-b161 -4a0a-b0fe-6a4fdeb35276.pdf.

Dillon, P., T. Hennessy, L. Shalloo, F. Thorne, and B. Horan. 2008. Future outlook for the Irish dairy industry: A study of international competitiveness, influence of international trade reform and requirement for change. Int. J. Dairy Technol. 61:16-29. https:// doi.org/10.1111/j.1471-0307.2008.00374.x.

Dohme-Meier, F., L. Kaufmann, S. Görs, P. Junghans, C. Metges, H. Van Dorland, R. Bruckmaier, and A. Münger. 2014. Comparison of energy expenditure, eating pattern and physical activity of grazing and zero-grazing dairy cows at different time points during lactation. Livest. Sci. 162:86-96. https://doi.org/10.1016/j.livsci 2014.01.006.

Doran, M. J., F. J. Mulligan, M. B. Lynch, M. O'Sullivan, A. G. Fahey, Z. C. McKay, E. L. Brady, C. Grace, M. O'Rourke, and K. M. Pierce. 2020. Effects of genotype and concentrate supplementation on milk composition and selected milk processability parameters in late-lactation spring-calving grazing dairy cows. Int. Dairy J. 114:104942. https://doi.org/10.1016/j.idairyj.2020.104942.

Dove, H., and R. W. Mayes. 2006. Protocol for the analysis of n-alkanes and other plant-wax compounds and for their use as markers for quantifying the nutrient supply of large mammalian herbivores. Nature Protocols 1:1680. https://doi.org/10.1038/nprot.2006.225.

Edmonson, A., I. Lean, L. Weaver, T. Farver, and G. Webster. 1989 A body condition scoring chart for Holstein dairy cows. J. Dairy Sci. 72:68-78. https://doi.org/10.3168/jds.S0022-0302(89)79081-0.

EPA. 2017. Water Quality in 2017: An Indicators Report. Accessed Jul. 1, 2021. https://www.epa.ie/pubs/reports/water/waterqua/ Water\%20Quality\%20in\%202017\%20-\%20an\%20indicators\%20 report.pdf.

Eslamizad, M., M. Dehghan-Banadaky, K. Rezayazdi, and M. MoradiShahrbabak. 2010. Effects of 6 times daily milking during early versus full lactation of Holstein cows on milk production and blood metabolites. J. Dairy Sci. 93:4054-4061. https://doi.org/10.3168/ jds.2010-3104.

Fahey, A. G., R. M. Marchant-Forde, and H. W. Cheng. 2007. Relationship between body weight and beak characteristics in oneday-old white leghorn chicks: Its implications for beak trimming. Poult. Sci. 86:1312-1315. https://doi.org/10.1093/ps/86.7.1312.

Ferris, C., F. Gordon, D. Patterson, C. Mayne, and D. Kilpatrick. 1999. The influence of dairy cow genetic merit on the direct and residual response to level of concentrate supplementation. J. Agric. Sci. 132:467-481. https://doi.org/10.1017/S0021859699006474.

Gaines, W. L., and F. A. Davidson. 1923. Relation between percentage fat content and yield of milk: Correction of milk yield for fat content. No. 245. University of Illinois Agricultural Experiment Station.

Gami, Y., M. Patel, M. Pawar, A. Chaudhari, B. Rathod, H. Panchasara, and S. Patil. 2018. Production performance, feed efficiency and their correlation in lactating Kankrej cows at organized farm. Indian J. Vet. Sci. Biotechnol. 14:61-63. https://doi.org/10 $.21887 /$ ijvsbt.14.3.15.

Huhtanen, P., E. Cabezas-Garcia, S. Krizsan, and K. Shingfield. 2015. Evaluation of between-cow variation in milk urea and rumen ammonia nitrogen concentrations and the association with nitrogen utilization and diet digestibility in lactating cows. J. Dairy Sci. 98:3182-3196. https://doi.org/10.3168/jds.2014-8215.

Hynes, D. N., S. Stergiadis, A. Gordon, and T. Yan. 2016. Effects of crude protein level in concentrate supplements on animal performance and nitrogen utilization of lactating dairy cows fed freshcut perennial grass. J. Dairy Sci. 99:8111-8120. https://doi.org/10 $.3168 /$ jds.2016-11110.

INRA. 2010. Alimentation des Bovins, Ovins et Caprins [Feeding of Cattle, Sheep, and Goats]. Quae Ed.

Ipharraguerre, I. R., and J. H. Clark. 2005. Varying protein and starch in the diet of dairy cows. II. Effects on performance and nitrogen utilization for milk production. J. Dairy Sci. 88:2556-2570. https: //doi.org/10.3168/jds.S0022-0302(05)72932-5.

Keim, J. P., and R. Anrique. 2011. Nutritional strategies to improve nitrogen use efficiency by grazing dairy cows. Chil. J. Agric. Res. 71:623-633. https://doi.org/10.4067/S0718-58392011000400019.

Kellaway, R., and T. Harrington. 2004. Feeding concentrates: Supplements for dairy cows. Landlinks Press.

Kennedy, J., P. Dillon, L. Delaby, P. H. Faverdin, G. Stakelum, and M. Rath. 2003. Effect of genetic merit and concentrate supplementation on grass intake and milk production with Holstein Friesian dairy cows. J. Dairy Sci. 86:610-621. https://doi.org/10.3168/jds .S0022-0302(03)73639-X.

Kopp, K., S. Robertson, and M. Friend. 2019. Barley grain supplementation in late gestation to twin-bearing Merino ewes grazing highbiomass and high-quality pasture does not increase lamb survival. Anim. Prod. Sci. 59:543-548. https://doi.org/10.1071/AN17378.

Kowalski, Z., J. Ludwin, P. Górka, M. Rinne, M. Weisbjerg, and W. Jagusiak. 2014. The use of cellulase and filter bag technique to predict digestibility of forages. Anim. Feed Sci. Technol. 198:49-56. https://doi.org/10.1016/j.anifeedsci.2014.09.008.

Lahart, B., L. Shalloo, J. Herron, D. O'Brien, R. Fitzgerald, T. Boland, and F. Buckley. 2021. Greenhouse gas emissions and nitrogen efficiency of dairy cows of divergent economic breeding index under seasonal pasture-based management. J. Dairy Sci. 104:80398049. https://doi.org/10.3168/jds.2020-19618.

Lee, C., A. Hristov, K. Heyler, T. Cassidy, M. Long, B. Corl, and S. Karnati. 2011. Effects of dietary protein concentration and coconut oil supplementation on nitrogen utilization and production in dairy cows. J. Dairy Sci. 94:5544-5557. https://doi.org/10.3168/ jds.2010-3889.

Lukas, M., K.-H. Sudekum, G. Rave, K. Friedel, and A. Susenbeth. 2005. Relationship between fecal crude protein concentration and diet organic matter digestibility in cattle. J. Anim. Sci. 83:13321344. https://doi.org/10.2527/2005.8361332x.

Mayes, R., C. Lamb, and P. M. Colgrove. 1986. The use of dosed and herbage n-alkanes as markers for the determination of herbage intake. J. Agric. Sci. 107:161-170. https://doi.org/10.1017/ S0021859600066910.

McEvoy, M., E. Kennedy, J. P. Murphy, T. M. Boland, L. Delaby, and M. O'Donovan. 2008. The effect of herbage allowance and concentrate supplementation on milk production performance and dry matter intake of spring-calving dairy cows in early lactation. J. Dairy Sci. 91:1258-1269. https://doi.org/10.3168/jds.2007-0710.

McKay, Z. C., M. B. Lynch, F. J. Mulligan, G. Rajauria, C. Miller, and K. M. Pierce. 2019. The effect of concentrate supplementation type on milk production, dry matter intake, rumen fermentation, and nitrogen excretion in late-lactation, spring-calving grazing dairy cows. J. Dairy Sci. 102:5042-5053. https://doi.org/10.3168/ jds.2018-15796.

Mulligan, F. J., P. Dillon, J. J. Callan, M. Rath, and F. P. O'Mara. 2004. Supplementary concentrate type affects nitrogen excretion of grazing dairy cows. J. Dairy Sci. 87:3451-3460. https://doi.org/10 .3168/jds.S0022-0302(04)73480-3.

O'Brien, B., S. Crosse, and P. Dillon. 1996. Effects of offering a concentrate or silage supplement to grazing dairy cows in late lactation on animal performance and on milk processability. Irish J. Ag. and Food Res. 35:113-125. https://www.jstor.org/stable/ 25562276 .

O'Sullivan, M., B. Horan, K. Pierce, S. McParland, K. O'Sullivan, and F. Buckley. 2019. Milk production of Holstein-Friesian cows of divergent economic breeding index evaluated under seasonal pasture-based management. J. Dairy Sci. 102:2560-2577. https:// doi.org/10.3168/jds.2018-15559.

Owens, L., W. Edwards, and R. Van Keuren. 1994. Groundwater nitrate levels under fertilized grass and grass-legume pastures. J. Environ. Qual. 23:752-758. https://doi.org/10.2134/jeq1994 $.00472425002300040020 x$.

Pakro, N., and P. Dillon. 1995. Preferential flow, nitrogen transformations and $15 \mathrm{~N}$ balance under urine-affected areas of irrigated and non-irrigated clover-based pastures. J. Contam. Hydrol. 20:329347. https://doi.org/10.1016/0169-7722(95)00077-1. 
Parsons, A. J., G. R. Edwards, P. C. D. Newton, D. F. Chapman, J. R. Caradus, S. Rasmussen, and J. S. Rowarth. 2011. Past lessons and future prospects: Plant breeding for yield and persistence in cool-temperate pastures. Grass Forage Sci. 66:153-172. https://doi .org/10.1111/j.1365-2494.2011.00785.x.

Prendiville, R., E. Lewis, K. Pierce, and F. Buckley. 2010. Comparative grazing behavior of lactating Holstein-Friesian, Jersey, and Jersey $\times$ Holstein-Friesian dairy cows and its association with intake capacity and production efficiency. J. Dairy Sci. 93:764-774. https://doi.org/10.3168/jds.2009-2659.

Reid, M., M. O'Donovan, J. P. Murphy, C. Fleming, E. Kennedy, and E. Lewis. 2015a. The effect of high and low levels of supplementation on milk production, nitrogen utilization efficiency, and milk protein fractions in late-lactation dairy cows. J. Dairy Sci. 98:5529-5544. https://doi.org/10.3168/jds.2014-9016.

Reid, M., M. O'Donovan, C. Elliott, J. Bailey, C. Watson, S. Lalor, B. Corrigan, M. Fenelon, and E. Lewis. 2015b. The effect of dietary crude protein and phosphorus on grass-fed dairy cow production, nutrient status, and milk heat stability. J. Dairy Sci. 98:517-531. https://doi.org/10.3168/jds.2014-8437.

Soyeurt, H., P. Dardenne, F. Dehareng, G. Lognay, D. Veselko, M. Marlier, C. Bertozzi, P. Mayeres, and N. Gengler. 2006. Estimating fatty acid content in cow milk using mid-infrared spectrometry. J. Dairy Sci. 89:3690-3695. https://doi.org/10.3168/jds.S0022 -0302(06)72409-2.

Steinshamn, H., M. Höglind, T. H. Garmo, E. Thuen, and U. T. Brenøe. 2006. Feed nitrogen conversion in lactating dairy cows on pasture as affected by concentrate supplementation. Anim. Feed Sci. Technol. 131:25-41. https://doi.org/10.1016/j.anifeedsci.2006 .02 .004 .

Tamminga, S. 1992. Nutrition management of dairy cows as a contribution to pollution control. J. Dairy Sci. 75:345-357. https://doi .org/10.3168/jds.S0022-0302(92)77770-4.
Van Soest, P. J., J. B. Robertson, and B. A. Lewis. 1991. Methods for dietary fiber, neutral detergent fiber, and nonstarch polysaccharides in relation to animal nutrition. J. Dairy Sci. 74:3583-3597. https://doi.org/10.3168/jds.S0022-0302(91)78551-2.

Van Vuuren, A., S. Tamminga, and R. Ketelaar. 1990. Ruminal availability of nitrogen and carbohydrates from fresh and preserved herbage in dairy cows. NJAS Wagening. J. Life Sci. 38:499-512. https://doi.org/10.18174/njas.v38i3B.16574.

Vazquez, O. P., and T. R. Smith. 2000. Factors affecting pasture intake and total dry matter intake in grazing dairy cows. J. Dairy Sci. 83:2301-2309. https://doi.org/10.3168/jds.S0022-0302(00)75117 -4 .

Whelan, S. J., K. M. Pierce, C. McCarney, B. Flynn, and F. J. Mulligan. 2012. Effect of supplementary concentrate type on nitrogen partitioning in early lactation dairy cows offered perennial ryegrass-based pasture. J. Dairy Sci. 95:4468-4477. https://doi.org/ $10.3168 /$ jds.2011-4689

\section{ORCIDS}

M. J. Doran () https://orcid.org/0000-0001-6756-2700 F. J. Mulligan ๑ https://orcid.org/0000-0002-1787-0788

M. B. Lynch (1) https://orcid.org/0000-0002-5301-6845

A. G. Fahey @ https://orcid.org/0000-0002-4594-5767

C. McDonnell ๑ https://orcid.org/0000-0002-4214-7559

K. M. Pierce @ https://orcid.org/0000-0002-2056-6189 